
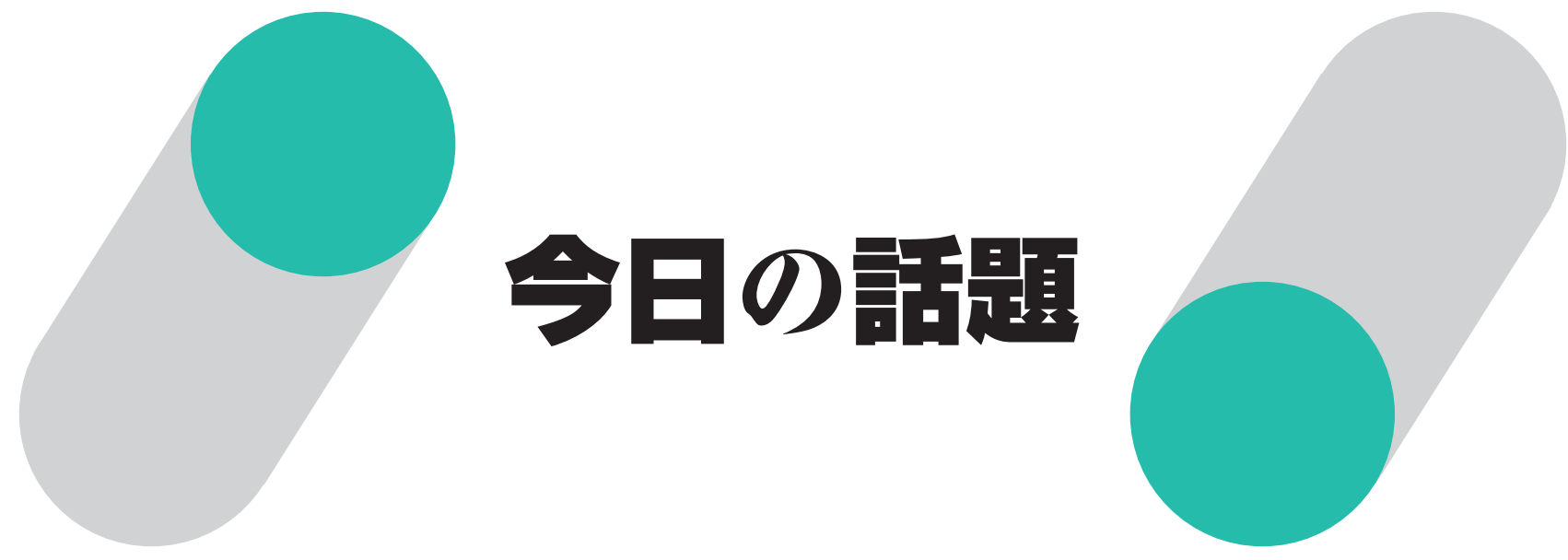

\title{
アーキア由来の超耐熱性セルラーゼ 耐熱性酻素を用いた高勃率バイオマス糖化
}

極限環境下で生育する特殊な微生物が発見され第三の 生物界アーキアと名づけらた。アーキアは真核生物に 近い特徴を示すが，原始的な生物が独自の進化を遂げた ものと考えられている. 産業技術総合研究所（産総研） では，アーキアの遺伝子情報を用いて，それらが生産す る超耐熱性酵素の産業利用を目的に研究を行ってき た ${ }^{(1,2)}$ 。ここでは, 超好熱性アーキアから, 現在注目さ れているバイオマス利用に必須の酵素であるセルロース 加水分解酵素セルラーゼについて紹介する.

セルロース系バイオマス有効利用技術開発において最 も困難な工程はセルロースの加水分解, すなわちセル ロースからグルコースを得る糖化工程である．セルラー ゼ酵素は本工程における産業用酵素として注目されてい る，既存のセルラーゼ酵素（系状菌由来）を用いる場 合, 反応最適温度が 50 度以下であり, この温度域で長 時間糖化反応を行う必要があるが, 反応中におけるバク テリアなどの雑菌繁殖により，得られたグルコースが消 費されるという問題が生じる。本問題解決のためには, バクテリアなどの死滅温度である $70^{\circ} \mathrm{C}$ 以上での酵素反 応が求められている。ささに, 高温酵素糖化反応には, 基質の溶解度向上や反応時間短縮などの利点も指摘され ている.

アーキアの一種であるPyrococcus horikoshii は最適生 育温度が 100 度で, 嫌気条件下で生育する ${ }^{(3)}$.われわれ は，ゲノム情報から，セルロース加水分解に有効なグル コース間の $\beta-1,4$ グルコシド結合を加水分解する酵素遺 伝子の探索を行った. その結果, セルロース加水分解に
関与すると思われる 2 種類の酵素遺伝子が見いだされ た. エンド型セルロース加水分解酵素エンド型セルラー ゼ (EGPh) と, エキソ型セルロース加水分解酵素ベー タグルコシダーゼ（BGLPh）である.アーキアの生育環 境にセルロースがどの程度存在するかについてはよくわ かっていないが, この 2 種類の酵素遺伝子の存在は, $P$. horikoshii生育環境下におけるセルロースの存在と, $P$. horikoshiiによるセルロース利用を示唆するものであ る.上記 2 種類の酵素において, BGLPhに関しては, その活性発現において特殊な界面活性化剂を要求すると いう久点があり ${ }^{(4)}$, 産総研において, その産業応用を断 念した。一方, EGPhは, 遺伝子配列から, Family-5に 属し， $\mathrm{N}$ 末端のシグナル配列，さらに，C末端に膜結合 と思われる配列の存在が確認されたことから，本酵素は 分泌型酵素であるがC末端の一部が細胞膜に埋め込まれ ている膜結合酵素であることがわかった ${ }^{(5)}$. 本酵素は, このままの型では発現調製が困難であるが，C末端部分 を削除することで発現調製が可能になる。さらに，X線 結晶構造解析の結果 ${ }^{(6)}$, 本酵素は安定な TIM バレル構 造を示し，高温下 $\left(105^{\circ} \mathrm{C}\right.$ 以下 $)$ で非結晶セルロースお よびカルボキシメチルセルロースなどに作用するエンド 型加水分解活性を示し, セルロースをセロビオースにま で加水分解することがわかった（図1).さらに，夕ン パク質工学的手法による大量発現にも成功し, 産業応用 への可能性が示された. 本酵素は, (株)ワコーケミカル から販売されている (http://www.wako-chem.co.jp/siyaku/info/enz/article/cellulase.htm). 


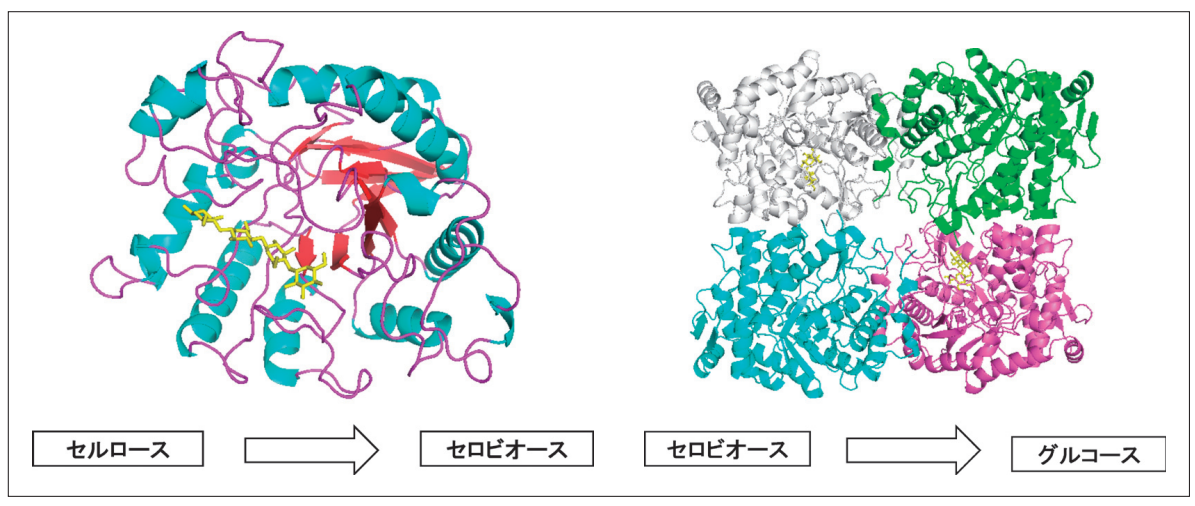

図 1・EGPh（左）およびBGLPf （右）の立体構造図
近縁種であるアーキアとしてPyrococcus furiosusus が挙げられる.P. furiosususのゲノム情報を調べると P. horikoshii と同様BGLとして2種類 (PF0073, PF0442) と, EGとして3種類（PF0076, PF0854, PF1861）のセル ラーゼ醳素遺伝子の存在が示されている。 そのなかで研 究報告例があり産業応用が期待される BGLPf (PF0073) は, Family-1に属するがBGLPh と異なり, 分泌シグナ ルが存在せず細胞内酵素であることが示されている．構 造機能解析の結果から, BGLPf (PF0073) は, TIMバ レル構造が会合体を形成することで極めて安定な 4 量体 構造を示し(7) (図1), セロビオースだけでなく種々のセ ロオリゴ糖をグルコースにまで加水分する活性が確認さ れた。さらに上記酵素を用いたセルロース加水分解実験 の結果，適度に前処理された非結晶セルロースであれ ば，高温条件下 $\left(105^{\circ} \mathrm{C}\right.$ 以下) に扔いて, EGPhと BGLPfにより完全糖化されることがわかった ${ }^{(8)}$. 一方, 結晶セルロースを主成分とする天然バイオマスの糖化工 程には, 少なくとも5 種の加水分解酵素が必要であり, 産総研に扔いて残り 3 種の耐熱性加水分解醳素の構造機 能解析が進行中である。

上記で示すように, バイオマス糖化に有効な耐熱性セ ルラーゼ遺伝子群, および, 酵素の実用性は確認されて いるが, 大量のバイオマスから低コストで可溶化糖を得 る必要性を考虑すると，いかに低コストでセルラーゼ醏 素を製造し, 高効率でバイオマス糖化反応に結びつける かが課題である. そこで, 京都府立大学との共同研究 で，上記遺伝子を植物葉緑体に導入することにより，植 物に耐熱性セルラーゼ䤉素を製造させ，加熱処理で植物 体セルロースからグルコースを取り出すことが可能な自 己糖化型植物の作成を試みた。われわれが開発した酵素 には超耐熱性があり高温域で最大活性を発揮するため,

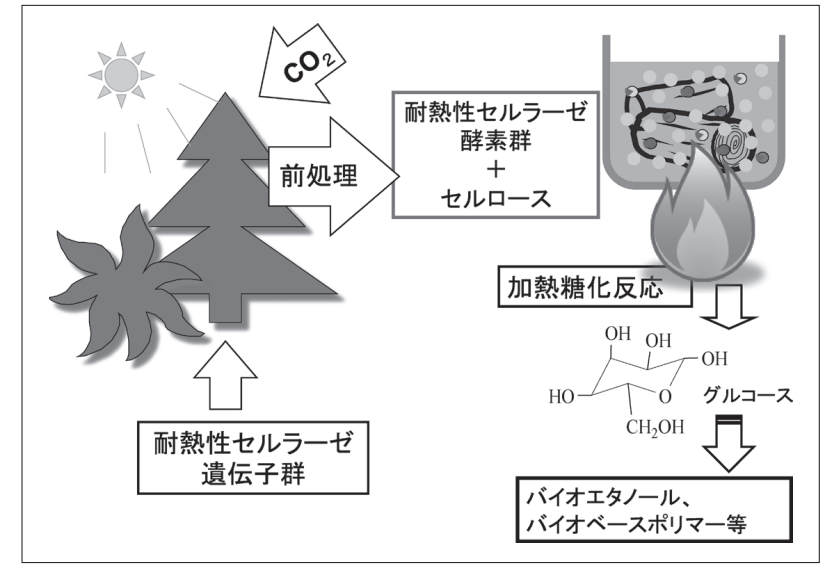

図 2 - 自己糖化植物のイメージ

植物の生育過程（低温）では低活性型で蓄積され，加熱 により酵素活性を発現させることができる（図2）。す なわち, 超耐熱性という特殊な酵素の性質を利用して, 収穫時に酵素活性を発現させ必要な物質を得ることが可 能になる。すでにタバコを用いた予備的実験により酵素 (EGPh, BGLPf) の大量発現に成功した. 当実験では, 植物中の全タンパク質の約 $10 \%$ に相当するセルラーゼ 酵素の発現に成功した ${ }^{(9)}$. 今後は，このシステムにおい て, 発現酶素にダメージを与えることなくバイオマスを 微粉砕し, 酵素反応を開始するための新規前処理技術開 発が必要である. 産総研において, 酵素にダメージを与 えないマイルドな前処理技術として, メカノケミカル法 およびウォータージェット方法 ${ }^{(10)}$ が考案され, その害 用化試験も開始されている.

1) AIST Today, 11, 8 (2003).

2) AIST Today, 12, 22 (2003).

3) J. M. González et al. : Extremophiles, 2, 123 (1998).

4) I. Matsui et al. : FEBS Lett., 467, 195 (2000).

5) Y. Kashima et al. : Extremophiles, 9, 37 (2005). 


\section{今日の話題}

6) H. W. Kim \& K. Ishikawa:Ptoteins, 78, 496 (2010).

7) Y. Kado et al. : Acta Crystallographica, Section F, 67, 1473 (2011).

8) H. W. Kim \& K. Ishikawa:J. Microbiol. Biotechnol., 20, $889(2010)$

9）特願 2007-209947（H19/08/10）「耐熱性酵素を葉緑体内
で発現するトランスジェニック植物」

10) Y. Watanabe et al. : Biopolymers, 95, 833 (2011).

(石川一彦，産業技術総合研究所バイオマスリファイ

ナリー研究センター)

\section{プロフィル}

石川一彦 (Kazuhiko ISHIKAWA)

$<$ 略歴 $>1984$ 年京都大学農学部食品工学 科修士課程修了／同年通商産業省工業技術 院化学技術研究所入所 / 1993 1995年 NRC (カナダ)-IBS博士研究員 / 1997〜 1998年CNRS（フランス）-AFMB博士研 究員 $/ 2001$ 年産業技術総合研究所主任研 究員 $/ 2012$ 年同研究所バイオマスリファ イナリー研究センター, 酵素利用チーム 長, 現在に至る。1992年農博 (京都大学) <研究テーマと抱負 >酵素の構造機能解析 と実用化，目標達成のためには何でも行う $<$ 趣味 $>$ 昆虫採集, 模型作製, スキー, ジョギング

井筒 ゆみ（Yumi IZUTSU）＜略歴> 1988年東京都立大学理学部生物学科卒 業/同大学大学院修士課程を修了後, 指導 教官の転勤に伴い移籍した広島大学大学院 理学研究科動物学専攻にて, 博士 (理学) 取得. 日本学術振興会特別研究員 PD とし て, 北海道大学大学院理学研究科に在籍. 北海道大学免疫科学研究所助手. 新潟大学 理学部生物学科助教を経て, 現在, 准教授 <研究テーマと抱負>動物の発生における 形態形成, 器官形成に関すること. 皮虐組 織のアポトーシスのメカニズム。両生類の 免疫系の発生＜趣味>研究室メンバーとグ ラフィックス iz（アイジー）を立ち上げ, 学会ポスターや予稿集表紙などのイラスト 作製に取り組んでいる。 下記URL. http:// www.sc.niigata-u.ac.jp/biologyindex/iz/ iz.html

魚住 武司 (Takeshi UOZUMI) <略 歴 $>1962$ 年東京大学農学部農芸化学科卒 業 / 1967 年東京大学大学院農学研究科博 士課程修了 (農博) $/ 1967$ 年鐘ヶ淵化学工 業株式会社発酵研究室研究員 / 1969 年東 京大学農学部農芸化学科助手 $/ 1978$ 年東 京大学農学部農芸化学科助教授 / 1987 年 東京大学農学部応用生命工学専攻教授／ 1999年東京大学名誉教授/同年明治大学 農学部教授 $/ 2009$ 年同上定年退職 $<$ 興味 をもっていること>エネルギー・環境問題 から宇宙の進化まで，いろいろな一般向け の講演会などを聴き，インターネットで $\mathrm{BBC}, \mathrm{CNN}$ な゙のニュースを見ています $<$ 趣味>草花の鉢植えを世話し, 週 $2 \sim 3$ 回の水中ウォーキングなどで体力を保ち, 時には旅行も楽しんでいます

宇 都宮 仁 (Hitoshi UTSUNOMIYA) <略歴>1983年京都府立大学大学院農学 研究科修了/同年国税庁入庁. 以後, 広島 国税局，高松国税局，国税庁，東京国税 局，福岡国税局に勤務／2001年酒類総合 研究所分析評価研究室主任研究員 $/ 2006$ 年同情報技術支援部門主任研究員 $/ 2007$ 年同情報技術支援部門副部門長 / 2010 年 同情報技術支援部門部門長 $/ 2011$ 年国税 庁酒類国際技術情報分析官＜研究テーマと 抱負 $>$ 日本産酒類の特性を世界に伝えたい <趣味>温泉つき登山, 居酒屋調查
大下 誠一（Seiichi OSHITA） 1976年東 京大学農学部農業工学科卒業 / 1978年三 重大学農学部助手 (農業機械学科) / 1986 年三重大学農学部助教授 (農業機械学 科) / 1994年東京大学農学部助教授（農業 工学科) / 2002 年東京大学大学院農学生命 科学研究科教授 (生物 - 環境工学専攻) <研究テーマと抱負>農産物の鮮度評価 法, 農産物の長期保存法 $<$ 趣味 $>$ 読書（乱 読), 行き先を決めない散歩

笠島 一郎（Ichiro KASAJIMA）＜略 歴 $>2003$ 年東京大学農学部生命化学学科 卒業 / 2008 年東京大学大学院農学生命科 学研究科応用生命工学専攻修了（農学博 士) /同年埼玉大学理工学研究科特別研究 員 $/ 2009$ 年東京大学分子細胞生物学研究 所特別研究員 $/ 2010$ 年埼玉大学環境科学 研究センター特別研究員 / 2011年奈良先 端科学技術大学院大学バイオサイエンス研 究科特任助教 / 2012 年農業・食品産業技 術総合研究機構花き研究所特別研究員 $<$ 研 究テーマと抱負 >画期的なトランスジェ ニック花きの作出と実用化と産業化, 面白 くて役に立つ遺伝子や現象を発見するこ と, 新しいプロトコルの開発 $<$ 趣味 $>$ 論文 書き，テニス，鉱物標本の採集および蒐 集, テレビドラマを観ること. ホームペー ジを作っています（http://kasajima.saku ra.ne.jp/home) 